\title{
Władza i rodowód. O wizerunku władcy w staroserbskiej literaturze
}

\begin{abstract}
Lis-Wielgosz Izabela, Władza i rodowód. O wizerunku wtadcy w staroserbskiej literaturze (Authority and Lineage. On the Image of Sovereign in the Old Serbian Literature). „Poznańskie Studia Slawistyczne” 5. Poznań 2013. Adam Mickiewicz University Press, pp. 173-184. ISBN 978-83-232-2636-9. ISSN 2084-3011.

The article refers to a problem of relationship between authority and genealogy, and to their specific functioning in the Old Serbian literature, that is in other words, in the hagiographical, historiographical, and hymnic texts. In all those works, the combination of the both ideas undoubtedly serves the ideological creation, regarding the image of sovereign together with the exposition of his extra-ordinary lineage and destiny which are tied to his place and role in the space of history, politics, religion, and culture. In the literature, this peculiar relationship is expressed by the two characteristic constructions of dynasty and genealogy. With regard to this representation, the dynastic construction is based on the model of biblical motif concerning Jesse's stem and functions as the saint osier of the family of Nemanjić. As for the second construction, of genealogy, it reveals itself as a component of the classical myth of historiography that determines the beginnings namely, the Serbian sovereign's mythical genesis that also concerns all his charismatic, saint family.
\end{abstract}

Keywords: authority; lineage; holiness; sovereign; Old Serbian Literature; hagiographical texts; historiographical texts; hymnic texts; state; orthodox Church; dynasty

W średniowiecznej rzeczywistości, jej porządku jurydycznym, politycznym, społeczno-kulturowym pozycja panującego jest w pełni i trwale sankcjonowana biblijną ideą boskiej proweniencji władzy, regulowana historyczną tradycją i recepcją definiującego ją zbioru znaczeń i wyobrażeń. Jego status jest jednoznaczny, stały i niepodlegający zmianie, ustalony staro- i nowotestamentowym kanonem. Władca jawi się w roli pomazańca, wykonawcy nakazu i planu Boga, wybrańca oraz dzierżyciela mandatu Ducha Świętego, namiestnika Chrystusa na ziemi (1 Sm 9,16; 16,13; Mdr 
6,3; Rz 13,1-7). Sprawujący władzę jest więc święty na mocy Bożego prawa, charyzmatu powołania i wybraństwa, a tak pojęta godność wprost odzwierciedla się właśnie w średniowiecznych systemach politycznych, których stanowi trzon, centralny punkt odniesienia dla wszelkich generowanych przez nie zjawisk historycznych, kulturowych, społecznych, przede wszystkim zaś państwowych i eklezjalnych. Na chrześcijańskim obszarze autorytet i rola panującego zostają zdefiniowane w odwołaniu do imperium i sacredotium, wraz z edyktem mediolańskim (313 roku), na wzór wcześniejszej (pogańskiej) tradycji duchowieństwo - biskupi otrzymują funkcje dygnitarzy cesarskich, a sam Konstantyn Wielki przyjmując tytuł Równego Apostołom, ogłasza się zwierzchnikiem nie tylko państwa, ale także Kościoła jako „biskup zewnętrzny” (Flis 2001: 279-280). W tym sensie pozycja imperatora jest podwójnie czy „absolutnie sakralna”, bo w specyficzny sposób, spajając obie władze, występuje on w roli jedynego panującego w imieniu Boga, pierwszego i wyłącznego zastępcy Najwyższego Rządcy. Pełniejszy wyraz znajdzie ta koncepcja w Noweli 6 cesarza Justyniana I, która ją nie tylko podtrzyma, ale także uzupełni o zbiór prawnych regulacji określających harmonijne już funkcjonowanie obu instytucji jako odrębnych, lecz współzależnych i równorzędnych „darów Bożych”, a jednocześnie potwierdzających cesarskie zwierzchnictwo nad nimi (Flis 2001: 280; Evans 2008: 78-79). Ten zalążek doktryny diarchii rozwinie potem ogłoszony przez cesarza Bazylego I Macedończyka wstęp do kodeksu prawnego, tekst Epanagogi, w którym również mowa jest o paralelizmie imperatora i patriarchy nazywanych najwspanialszymi i koniecznymi częściami państwa, przy czym zwierzchnik Kościoła otrzymuje już znacznie większą decyzyjność i niezależność (Schmemann 2001: 224-226; Wieczerza mistyczna 1988: 136-137). Pomimo tej swoistej definicji władzy obowiązującej pierwotnie na całym chrześcijańskim obszarze, sakralna pozycja panującego jest później odmiennie budowana w jego części zachodniej i wschodniej. Podczas gdy na Zachodzie dość szybko następuje polityczne rozdzielenie instytucji państwa i Kościoła, to na Wschodzie dalej funkcjonuje i rozwija się idea symfonii, harmonii obu władz sakralnych ze swej natury wyznaczających idealny porządek (taxis); „Diarchia władzy nieokreślona prawnie, ale pośrednio z prawa wynikająca, stanowiąca odbicie dogmatu Wcielenia, pozwalała rozumieć świętość władzy jako świętość wynikającą ze współpracy z Wolą Bożą" (Gil 2005: 66). 
Szczególną jej odmianą jest sformułowana w serbskim zbiorze prawnym sporządzonym przez Savę Nomokanonie (Zakonopravilu sv. Save) (Петровић 2002: 27-45; Мошин 1979: 101-128; Богдановић 1979: 9199) religijno-polityczna koncepcja harmonijnego współistnienia, równorzędności władzy państwowej i kościelnej, co znajdzie trwałe odzwierciedlenie między innymi w literackich i plastycznych przedstawieniach ojców założycieli - Simeona i Savy, a potem ich następców. Hagiografia, hymnografia i ikonografia realizują temat świętości władzy w odwołaniu do uniwersalnej koncepcji, a jednocześnie do rodzimego programu cerkiewno-państwowego, kreśląc wizerunek pierwszego władcy, wielkiego żupana Stefana Nemanji, zwykle i prawie wyłącznie w kontekście diarchicznym, wynosząc go wraz z pierwszym arcybiskupem Savą na pozycję fundatorska. Niemalże we wszystkich realizacjach jego status określa paradygmat założycielski i wspomniana idea symfonii opartej na trwałej i określonej ideologicznie relacji między kolejnymi pokoleniami rządzących z charyzmatycznej dynastii Nemanjiciów i ich sukcesorami Lazareviciami oraz Brankoviciami oraz zwierzchników cerkiewnych (Маријановић-Душанић 1997; Gil 2005: 69).

Interesujące jest to, że w poświęconych wielkiemu żupanowi tekstach (pióra Savy, Stefana Pierwoukoronowanego czy Domentijana i Teodosija) zostaje pominięty, przemilczany lub tylko zdawkowo wspomniany okres poprzedzający jego panowanie, co wydaje się ideologicznym zabiegiem mającym na celu prezentację panującego jako protoplasty dynastii i fundatora niezależnej państwowości. Brak refleksji na temat pochodzenia zdaje się intencjonalnym podkreśleniem początku, szczególnego wybraństwa i daru władzy, a rodzajem genealogicznej kompensacji jest adaptacja biblijnego motywu pnia Jessego, który rychło legnie u podstaw literacko-ikonograficznej konstrukcji dynastycznej - serbskiego krzewu winnego (svete loze). Zwykle, wespół z Savą, Nemanja jest prezentowany w roli ojca i nazywany „pięknym kwiatem z dobrego korzenia” (оть влагаaro

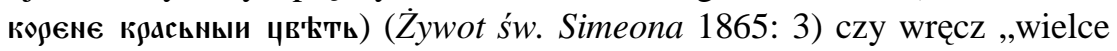
płodnym korzeniem drzewa oliwnego/rajskiego zasadzonego prawicą Pań-

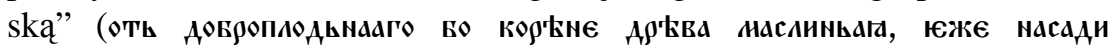
дєсьница владичьнга), z którego wyrastają następсy niczym „chwalebne i różnorodne pędy, niczym rajskie kwiaty" (догрохвальныю и яного-

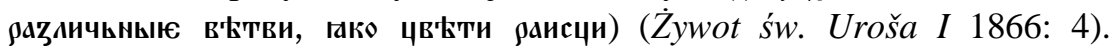


Kolejni władcy jawią się jako wierne odwzorowanie lub nawiązanie do ojców założycieli, tradycyjnie są nazywani następcami świętego korzenia, latoroślą swych prarodziców, konarami i jednorodnymi pędami, co ma podkreślać ciagłość i legitymizację władzy ${ }^{1}$. Najpełniejszą i najbardziej plastyczną realizację idea dynastyczna osiaga w tekstach arcybiskupa Danila II, autora żywotów Stefana Uroša I, Stefana Dragutina, Stefana Milutina i Jeleny. Dynastia jako wiecznie zielone i płodne drzewo (Ps 92 (93), 13-15), funkcjonując na wzór pnia Jessego, staje się czytelnym znakiem trwałości i szczególnego przymierza z Bogiem. W taki oto symboliczny sposób idea władzy i genealogii jest rozwijana w najstarszych serbskich utworach hagiograficznych, hymnograficznych oraz przedstawieniach ikonograficznych - kompozycjach zachowanych w wielu monasterach między innymi w Gračanicy z ok. 1321, Peci z ok. 1334, Dečanach z 1350, Matejču z 1360 roku (Маријановић-Душанић 1994: 60-64). O trwałości tej konstrukcji przedstawieniowej świadczą późniejsze, znacznie oddalone czasowo realizacje literackie Pajsija Janjevca, który kreśląc wizerunki pierwszego króla Stefana (św. Simona) i ostatniego cara Uroša V, sięga do gotowych już rozwiązań, schematów ideowo-wyrażeniowych. W żywocie prologowym św. Simona pozycja władcy jest wyraźnie budowana w odwołaniu do motywu charyzmatycznego rodu - svete loze; serbski król jest wprost określany jako: „ten święty i czcigodny ojciec nasz Simon [co] wyrósł/wykiełkował z pobożnych rodziców, Simeona zwanego Nemanją

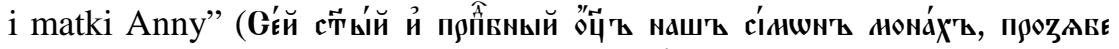

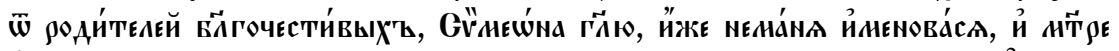
Äнны) (Srbljak 1761; v. Srbljak 1765, Srbljak 1861; Србљак 1970)². Analogicznie jest ów topos wykorzystany w tekście służby poświęconej młodemu carowi, o którym autor powiada, że ,z korzenia szlachetnego wy-

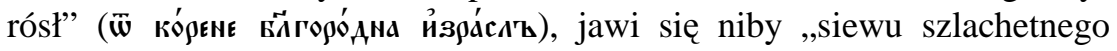

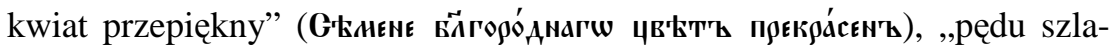

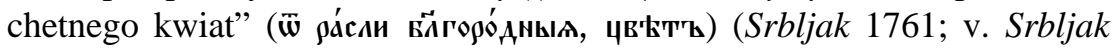
1765, Srbljak 1861; v. Србљак 1970). Koncepcja ścisłego powiązania

\footnotetext{
${ }^{1}$ Zespolona z konstrukcją rodową idea władzy stanie się wykładnią świętości i podstawową strategią gloryfikacji władcy w tekście żywota cara Dušana.

${ }^{2}$ W tekście w tzw. belgradzkim Srbljaku z 1861 roku wymienienie Simeona i Anny przywołuje też formułę wszystkich cerkiewnych rozesłań, w zakończeniu wymienia się też rodziców Maryi, a tym samym drzewo Nemanjiciów upodabnia się do drzewa Jessego.
} 
władzy i genealogii okazuje się zatem niezwykle trwałym ujęciem, a w siedemnastowiecznych kompozycjach służy ponadto wykazaniu trwałości i kontynuacji tradycji literackiej, kulturowej, przede wszystkim zaś politycznej i ideologicznej. Przy całej wierności trwałym schematom ideowym i przedstawieniowym w tekście żywota św. Uroša dodatkowo zastosowana jest właściwa nie hagiografii, lecz historiografii strategia kreowania wizerunku władcy za pomocą pogłębionego, znakomitego rodowodu. Zasadniczo w utwór zostaje wbudowany starszy rodosłów, który w roli przodków serbskiego cara sytuuje Konstancję siostrę imperatora Konstantyna, przez co wyeksponowana jest nie tylko ciagłość władzy, ale też właśnie szlachetne, wręcz mityczne pochodzenie (Стојановић 1927: 1-39; Cmape српске биографије 1936; Пајсије Патријарх 1993) ${ }^{3}$. Jest to oczywista zmiana, ideowe czy nawet ideologiczne przesunięcie prezentacji władzy w aspekcie genealogicznym, dotąd wizerunki kolejnych panujących, następców wielkiego żupana Stefana Nemanji są bowiem kreowane w odwołaniu wyłącznie do jego postaci. Jak zauważa K. Jireček, to właśnie on stoi na początku, na czele wszystkich władców, zwykle jako praojciec (Jиречек 1952: 147). Wypada przypomnieć, że taka pozycja jest lansowana tylko przez część tekstów, gdyż niejednokrotnie występuje wraz z pierwszym arcybiskupem Savą. Tak też jest przedstawiany w ikonografii na przykład na fresku w monasterze Mileševa, a w kompozycjach rodowych zwykle z Savą i królem Stefanem w pierwszym rzędzie, u podstaw serbskiego krzewu winnego w geście szeroko rozłożonych rąk symbolicznie podtrzymuje całą konstrukcję, czego przykładem są chociażby wyobrażenia w Gračanicy, Dečanach czy Peci (Марјановић-Душанић 1994: 60-64). W utworze Pajsija tego rodzaju wzmocnienie kreacji ostatniego serbskiego cara, dzięki głębokiemu rodowodowi, w szerszej perspektywie służy spotęgowaniu narracji dynastycznej i samej idei państwowej, a w czasach tzw. drugiego patriarchatu (odnowionego w 1557 roku) spajającego kompetencje obu władz, także nieistniejącego już państwa, podbudowie pozycji zwierzchnika cerkiewnego w roli dziedzica i kontynuatora wielkiej tradycji. Co więcej, funkcjonująca do połowy XVI wieku doktryna diarchii po odnowie patriarchatu i przy nieistniejącej serbskiej państwowości, zdaje się w swej klasycznej formule nieaktualna. Cerkiew staje się bowiem jedyną i zastępującą państwo instytucją, a jej zwierzchnik politycznym

\footnotetext{
${ }^{3}$ Tego fragmentu brak w wydaniu I. Ruvarca (Żywot cara Uroša 1867: 213-232).
} 
przywódcą - etnarchą. Tego rodzaju przekształcenie tradycyjnej formuły odzwierciedla się nie tylko w literaturze, ale też ikonografii, czego dobitnym przykładem może być powstała 1594 roku kompozycja w monasterze Orahovica;

Oparte na kompozycji lozy Nemanjiciów freskowe przedstawienie Stefana Nemanji jako etnarchy - zarówno politycznego, świeckiego, jak też religijnego przywódcy Serbów, stanowi pierwszą tak wyraźnie zaakcentowaną reinterpretację ustalonego i dotychczas dominującego szablonu malarskiego; poprzez postać św. Simeona - władcy-mnicha uwielbieni zostają patriarchowie pećcy jako idealni następcy zwierzchników państwa i Cerkwi epoki Nemanjiciów (Gil 2005: 77; cf. Медаковић 1988: 112; cf. Маријановић-Душанић 1994: 60-64 ).

Warto podkreślić, że $\mathrm{w}$ takiej roli będą do końca istnienia tzw. drugiego patriarchatu (do 1766 roku) oficjalnie występować kolejni zwierzchnicy cerkiewni, ich wizerunek i pozycję będzie określać miano przywódców politycznych (Gil 2005: 77; Гавриловић 1991: 40).

W odróżnieniu od hagiografii, hymnografii i ikonografii relacja władzy i genealogii w tekstach historiograficznych wyraża się nie tylko w odwołaniu do idei świętej łozy, lecz przede wszystkim za pomocą skonstruowanego rodowodu, przez jego pogłębienie i mitologizację. W utworach realizowanych $w$ ramach obu tradycyjnych gatunków - rodosłowu i latopisu, związek władzy i pochodzenia stanowi komponent klasycznego historiograficznego mitu początku sytuującego serbskich zwierzchników - ojców założycieli i ich następców w roli prawowitych spadkobierców wielkiego dziedzictwa, kontynuatorów uniwersalnej i rodzimej tradycji. Pogłębiony rodowód jest tu więc celowym zabiegiem służącym wykazaniu dawności, szlachetnych korzeni serbskiego władcy i całej dynastii, a przez to ujawniającym podstawową funkcję mitu wyznaczającego początki, które zawsze muszą wiązać się z wybitną i powszechnie znaną osobistością w tym przypadku przez siostrę z pierwszym chrześcijańskim cesarzem. Związek przez pokrewieństwo $\mathrm{z}$ wielkim imperatorem nie tylko nobilituje, ale też wynosi serbskiego władcę do godności prawowitego i godnego dziedzica, następcy i naśladowcy wielkiego czynu pradziada (Ossowski 1966: 129). Staroserbskie utwory historiograficzne podnoszą temat znakomitego pochodzenia dość szczegółowo i na tle przełmowych wydarzeń, zdarza się, że zawarta w nich narracja niejednokrotnie sięga czasów bi- 
blijnych, a następnie pierwszych wieków chrześcijaństwa, z którymi powiązana zostaje serbska geneza. Po raz pierwszy informacja taka pojawia się w Żywocie despoty Stefana Lazarevicia Konstantyna Kosteneckiego, gdzie trafia najprawdopodobniej pod wpływem przekładu bizantyńskiej kroniki Joannesa Zonarasa, a być może zostaje także zapożyczona, zresztą via przekaz ustny, z bardzo popularnego $\mathrm{w} \mathrm{XV}$ wieku włoskiego dzieła I Reali di Francia zawierającego bezpośrednią wzmiankę o rodzicach pierwszego francuskiego władcy - siostrze Konstantyna Licynii oraz jej mężu Licyniuszu (Банашевић 1955: 6-10; Da Barberino 1947: I, 8; Graf 1923: 462). Zaadaptowana konstrukcja rodowa wkrótce stanie się stałym i obligatoryjnym elementem narracji o serbskich początkach - przodkach Stefana Nemanji. Jej podstawę niemalże każdorazowo stanowi wieść o tym, że ze związku Konstancji z cesarzem Licyniuszem ma się narodzić pradziad Nemanji - Bela Uroš, co więcej, zawsze w tej relacji eksponowana jest bliskość z samym Konstantynem Wielkim:

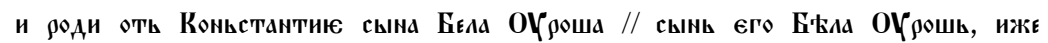

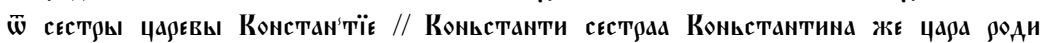

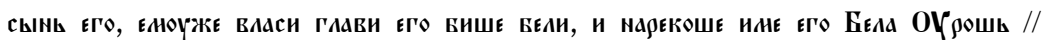

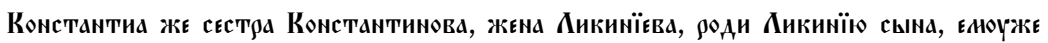

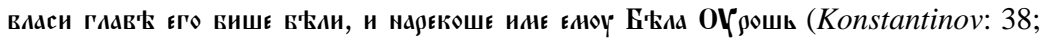
Karlovački: 7; Zagrepski, Vrhobreznički: 5; cf. Pejatovićev: 40, Ruvarčev: 79, Novakovićev: 101, Hadži-Jordanov: 112; Pajsijev: 5; Ćorovićev: 69).

Należy zwrócić uwagę również na kreację wizerunku Licyniusza nazywanego tu Serbem czy nawet serbskim cesarzem (Ликинию в бшє даль-

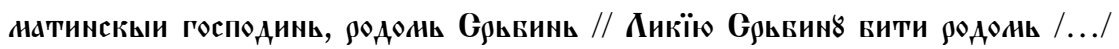

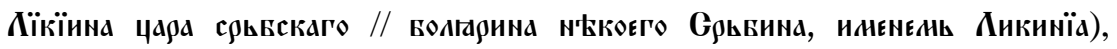
a jednocześnie, co nie jest zbyt częste, zgodnie z faktami historycznymi ze względu na prześladowania chrześcijan, jakich się dopuszcza, przedstawianego jako ciemiężyciel, bałwochwalca, „bezbożny” władca:

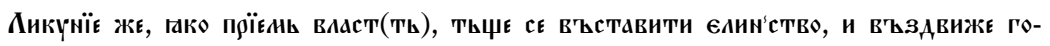

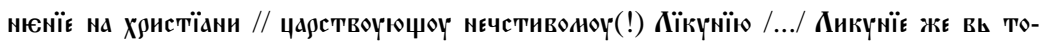

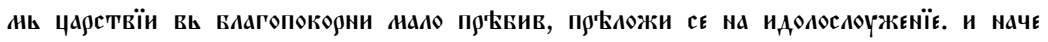

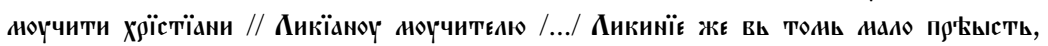

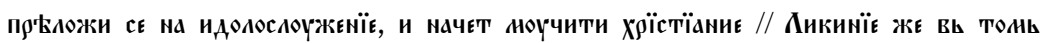

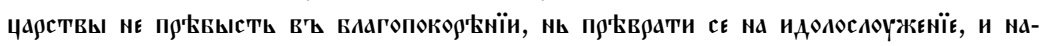


четь ноүчити хрїстїаны (Konstantinov: 38, Karlovački: 1, 3; Vrhobreznički: 3; Karlovački: 5, Zagrepski, Pajsijev: 2, 5; Vrhobreznički: 5).

W dalszej części wszystkie rodosłowy zawierają bez mała jednakową relację o spowodowanej pogromami chrześcijan ucieczce Beli Uroša (lub jego ojca) do Zahumlja (albo na ziemię gocka, a potem serbska), gdzie z jego mariażu z francuską księżniczką Anną rodzą się synowie: Zavida, Stracimir, Prvoslav i Tehomil - ojciec Nemanji (Karlovački, Zagrepski, Pajsijev, Vrhobreznički: 7). Opowieść o szlachetnym pochodzeniu wyraźnie stanowi tu mitolgiczny i ideologiczny grunt dla relacji o samym Stefanie Nemanji, który jawi się jako prawowity dziedzic ziem praojców (Rıdстӥ̈о шпас\$ет с

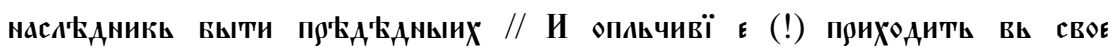

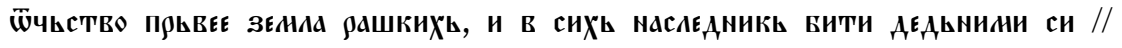

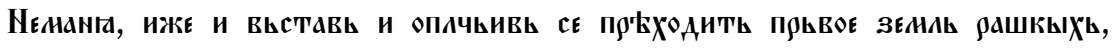
и вь сихь насл'фдникь высть дединьки(!)), na wzór wybitnego pradziada Konstantyna jako władca wielki, samodzierżawny (вєликы жоүпан сd-

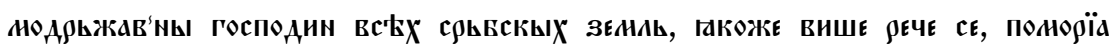

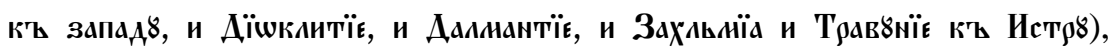
przede wszystkim zaś niesłychanie pobożny i miłujący wiarę chrześcijańską, co można odczytywać również jako sugestię swoistego zmycia Licyniuszowego grzechu (Karlovački, Zagrepski: 8; Vrhobreznički: 7; Karlovački: 10). Aluzja jest wyraźniejsza już w starszych latopisach podkreślających zasługi Nemanji - Simeona w utwierdzaniu wiary i zwalczaniu herezji, a przez to implikująca odkupienie przewiny jednego i kontynuację szlachetnego czynu drugiego z prarodziców; pojawia się bowiem na pozycji ojca, pogromcy, oświeciciela i nauczyciela:

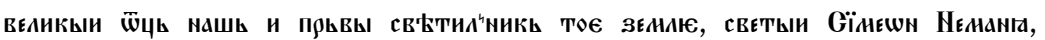

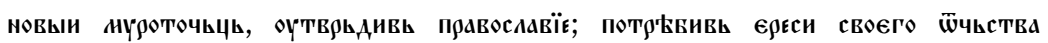

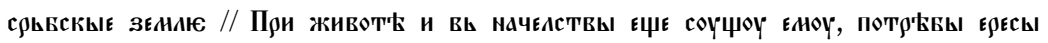

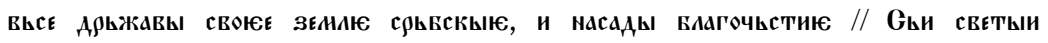

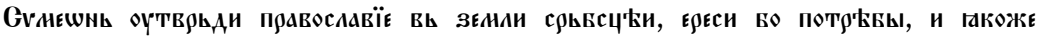

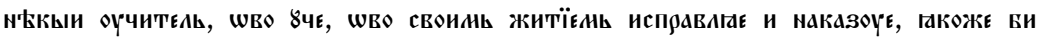

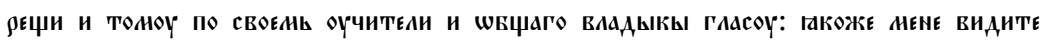
творєща, сицє и вы творитє (Koporinjski, Pećki, Studenički: 8; cf. Cetinjski: 8; Vrhobreznički: 142).
} 
Utrwalona w rodosłowach i starszych latopisach konstrukcja genealogiczna ewidentnie służąca podbudowie pozycji serbskiego władcy jest rekapitulowana w tzw. młodszych tekstach latopisowych. W zasadzie jedyną różnicą jest kierunek zawartej w nich wszak identycznej narracji. Wprowadzenia nie stanowi już stopniowo zawężana, sięgająca czasów Stefana Nemanji historia ogólna, lecz sama figura założyciela wraz z gotowym rodowodem. Jest więc przedstawiany jako wielki żupan z rodu - korzenia szlachetnego wyrosły, prawnuk Konstancji siostry wielkiego cesarza Konstantyna, a dodatkowo z pokolenia władców raškanskich spokrewnionych $\mathrm{z}$ cezarem Augustem:

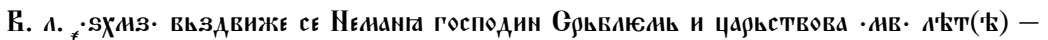

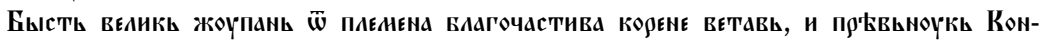

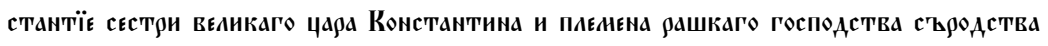
Явгоүста кесара (Ruvarčev II: 419; cf. Sofijski II, Vasićev, Podgorički: 429, Vukmanovićev, Senički, Magaraševičev, Hilandarski: 465; Verkovičev, Ostojićev: 487; Jankov, Dečanski: 504; Sečenički: 520; cf. Belopoljski: 549; Koviljski: 559; Brankovićev: 1058-1060).

W narracji zwykle zostają przywołani bezpośredni przodkowie - Bela Uroš i Tehomil, po czym następuje właściwa już opowieść o Nemanji, zespalająca mit pochodzenia z założycielskim. Wzór tego połączenia znajduje się w uważanym za najstarszy rodosłów fragmencie tekstu żywotowego Konstantyna Kosteneckiego, gdzie jest ono kombinacją genealogii i idei świętej tozy, dodatkowo podbudowaną biblijnym motywem Bożej łaski i wybraństwa. Autor przywołuje motyw drzewa dynastycznego (rodu Nemanjiciów), którego rozkwit, jak powiada, ze względu na wspaniałych przodków dziwić nie może: и нного оүго моза та пюоцвьте. Яце Констаньтыюю, ащє ли же и Ликиниюмь, н'大сть чоүаьно, ро czym kreśli analogiczne do rodu Abrahama, Izaaka i Jakuba, powołanie serbskiej dynastii: Исаdв

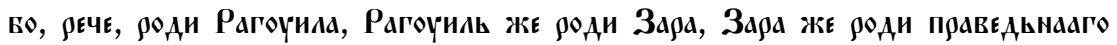

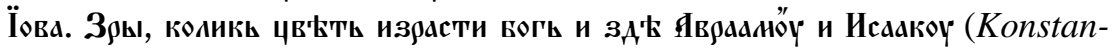
tinov: 39). W wielu rodosłowach i latopisach pogłębiony rodowód splata się z konstrukcją rodową i ideą diarchicznq, co wyraża już opowieść o początkach serbskiego (Nemanjiciowskiego) państwa i Cerkwi będąca swoistą realizacją mitu założycielskiego. Jego filarami są rzecz jasna Stefan Nemanja, Sava i Stefan Pierwoukoronowany, których wizerunki bu- 
dowane są w ideologicznej perspektywie, w kontekście władzy państwowej i cerkiewnej. Jawią się więc w roli spadkobierców oraz naśladowców czynu wielkich przodków, z Bożej woli obdarowani najpierw wieńcem

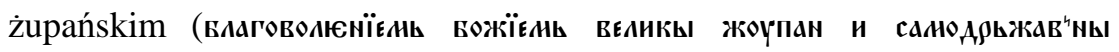

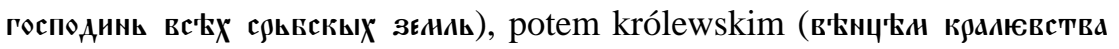
/.../ в'ъ слоүжв8 кралюв'ств8), a także żezłem arcybiskupim - ze zwy-

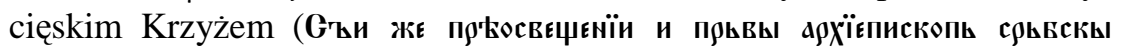
Gава // арXїєпископскїи жєзаль съ көстольъ) (Karlovački: 10, 12, 11; Ruvarčev I: 167). Kreowana na podobieństwo Konstantynowe postać Stefana Nemanji sama staje się wzorcowa w sferze władzy i wiary (Плюханова 1995: 111). Pierwszy król jest przedstawiany jako prawowity następca, „we wszystkim podobny ojcu”, władca „Boga miłujący, łaskawy, dobry, pokorny, mądry...” (Сефань же, сынь югш, прїєнь влагословенїє

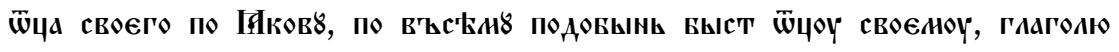

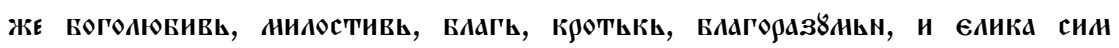

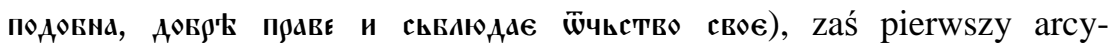
biskup jako niewzruszenie umacniający ,świętą wiarę prawosławną przez

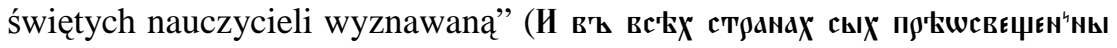

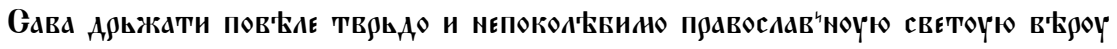
светияи оүчитеАи ПюПов'Едан'н४ю) (Koporinjski: 122; Karlovački: 11). Та swoista triada świętości, zespolona w jedną założycielską figurę stanowi ideał, trwały punkt odniesienia dla kreacji wizerunków kolejnych panujących, których cechy zawsze pokrywają się z ideologicznym kanonem określającym prawowitego i dobrego władcę. Opowieść funkcjonująca w granicach metafory dziedziczenia, następstwa władzy tworzy trwałą strukturę mitu politycznego, który utrwala i sankcjonuje określoną kolejność i porządek.

$\mathrm{Z}$ oczywistych względów artykuł jedynie sygnalizuje problem relacji władzy i genealogii, ich specyficznego funkcjonowania w staroserbskiej literaturze - tekstach hagiograficznych, hymnograficznych i historiograficznych. Jednak nawet w skromnej liczbie przytoczone przykłady ujawniają szeroko i trwale obecny mechanizm ideologicznej kreacji wizerunku panującego, eksponowania szczególnego pochodzenia i przeznaczenia, miejsca i roli w przestrzeni historycznej, politycznej, eklezjalnej, kulturowej. Związek władzy i rodowodu wyrażają w literaturze dwie charaktery- 
styczne konstrukcje - dynastyczna, ukształtowana na wzór biblijnego motywu pnia Jessego i funkcjonująca jako sveta loza Nemanjiciów, oraz rodowodowa - stanowiąca komponent klasycznego mitu historiograficznego określającego początki, mityczną genezę serbskiego władcy, a także całego rodu uważanego przez to za charyzmatyczny i święty.

\section{Literatura}

Банашевић М., 1955, Летописци о пореклу Немањића, „Прилози за књижевност, језик, историју и фолклор", ks. 21, z. 1-2, Београд, s. 6-10.

Богдановић Д., 1979, Крмчија Светога Саве, w: Сава Немањић - Свети Сава. Историја и предағе, red. В.Ј. Ђурић, Београд, s. 91-99.

Da Barberino A., 1947, I Reali di Francia, a cur. G. Vandelli, G. Gambarin, Bari, lib. I, cap. VIII.

Evans J. A., 2008, Justynian i Imperium Bizantyńskie, przeł. B. Godzińska, Warszawa.

Flis A., 2001, Chrześcijaństwo i Europa. Studia z dziejów cywilizacji Zachodu, Kraków.

Гавриловић С., 1991, Српски нащионални програм патријарха Арсенија IV Јовановића Шакабенте из 1736/37 2., „Зборник Матице Црпске за историју” nr 44, Нови Сад.

Gil D., 2005, Prawostawie. Historia. Naród. Miejsce kultury duchowej w serbskiej tradycji i wspótczesności, Kraków.

Graf A., 1923, Roma nella memoria e nelle imaginazioni del Medio Evo, Torino.

Јиречек К., 1952, Историја Срба, t. I, Београд.

Медаковић Д., 1988, Представа српских владара-светитеља у XVIII веку, w: Барок код Срба, Београд.

Маријановић-Дишанић С., 1994, Владарске инсигније и државна симболика у Србији од XIII до XV века, Београд.

Маријановић-Дишанић С., 1997, Владарска идеологија Немањића, Београд.

Мошин В., 1979, Правни списи Светога Саве, w: Сава Немањић - Свети Сава. Историја и предање, red. В.Ј. Ђурић, Београд, s. 101-128.

Ossowski S., 1966, Więź społeczna i dziedzictwo krwi, w: S. Ossowski, Dzieła, t. 2, Warszawa.

Пајсије Патријарх, 1993, Сабрани списи, przeł. Д. Богдановић, Т. Јовановић, Београд.

Петровић М., 2002, Свети Сава као састављач и преводилаи Законоправила српског Номоканона, „Историјски часопис” $\mathrm{nr}$ 49, s. 27-45. 
Плюханова М., 1995, Сюжеты и символи Московского Царства, Санкт-Петербург.

Стојановић Љ., 1927, Стари српски родослови и летописи. Зборник за историју, језик и књижевност српског народа, ks. XVI, Сремски Карловци. Rodosłowy i Latopisy: Konstantinov, Karlovački, Zagrepski, Vrhobreznički, Pejatovićev, Ruvarčev, Novakovićev, Hadži-Jordanov, Pajsijev, Ćorovićev, Pećki, Koporinjski, Studenički, Vrhobreznički, Ruvarčev II, Sofijski II, Vasićev, Podgorički, Vukmanovićev, Senički, Magaraševičev, Hilandarski, Verkovičev, Ostojićev, Jankov, Dečanski, Sečenički, Belopoljski, Koviljski, Brankovićev, Ruvarčev I.

Schmemann A., 2001, Droga prawosławia w historii, przeł. H. Paprocki, Białystok.

Srbljak (Pravila molebnaja svjatih serbskih), Rimnički z 1761 r. (starodruk ze zbiorów Biblioteki Macierzy Serbskiej, sygn. R 18, Sr II).

Srbljak (Pravila molebnaja svjatih serbskih), Moskiewski z 1765 r. (starodruk ze zbiorów Biblioteki Macierzy Serbskiej, sygn. R 18, Sr IV).

Srbljak (Pravila molebnaja svjatih serbskih), Belgradzki z 1861 r. (starodruk ze zbiorów Biblioteki Macierzy Serbskiej, sygn. R 19, Sr IV).

Србљак. Службе. Канони. Акатисти, 1970, oprac. Ђ. Трифуновић, ks. 3, Београд.

Cтаре српске биографије XV и XVII века. Цамблак. Константин. Пајсије, 1936, przeł. Л. Мирковић, przedmowa П. Поповић, Београд.

Wieczerza mistyczna. Anafory eucharystyczne chrześcijańskiego Wschodu, 1988, wyb., oprac., przeł. H. Paprocki, Warszawa.

Żywot św. Symeona, 1865, w: Живот Светога Симеуна и Светога Саве, napisał Доментијан, wyd. Ђ. Даничић, Београд.

Żywot cara Uroša, 1867, w: „Гласник Српског Ученог Друштва”, ks. IV, z. XXI (старога реда), Београд.

Żywot św. Uroša I, 1866, w: Животи краљева и архиепископа српских написао архиепископ Данило и други, wyd. Ђ. Даничић, Загреб. 